\title{
PERAN GURU PAI DALAM PENINGKATKAN SIKAP SPIRITUALITAS SISWA MELALUI PEMBACAAN SURAT-SURAT PENDEK DI SMK PANCASILA MOJOWARNO JOMBANG
}

\author{
Ahmad Budiyono \\ Prodi Pendidikan Agama Islam, STIT Al-Urwatul Wutsqo Jombang \\ e-mail: onobudi.stituw@gmail.com \\ Arif Rahman Hakim \\ Prodi Pendidikan Agama Islam, STIT Al-Urwatul Wutsqo Jombang \\ e-mail: ayipuyip@gmail.com \\ M. Syahril A.S \\ Prodi Pendidikan Agama Islam, STIT Al-Urwatul Wutsqo Jombang \\ Abstract: Spiritual attitude is a reflection of religious character. \\ Religion is a character value that is related between humans and their \\ God, Spiritual attitudes can be implemented as a very good way to \\ always be grateful for the blessings of Allah SWT. The results \\ showed that the role of Islamic religious education teachers in \\ improving students' spiritual attitudes included; consistency \\ (istiqomah), humility (tawadu'), strive and surrender (tawakal), \\ sincerity (sincereness), totality (kaffah), balance (tawazun), integrity \\ and perfection (ihsan). as for a. supporting factors are adequate \\ facilities and infrastructure, as well as a comfortable environment. \\ b. the inhibiting factor is the limited time for meetings and \\ interactions between teachers and students. Lack of motivation and \\ parental attention. There is no written assessment of emotional and \\ spiritual intelligence.
}

Keywords: Teacher's Role, Spiritual Attitude, Students

\section{PENDAHULUAN}

Pendidik merupakan salah satu komponen yang paling penting dalam proses pendidikan. Di pundaknya terletak tanggung jawab yang besar dalam upaya mengantarkan peserta didik ke arah tujuan pendidikan yang telah dicitakan. Secara umum pendidik adalah mereka yeang memiliki tanggung jawab mendidik. Mereka adalah manusia dewasa yang karena hak dan kewajibannya melaksanakan proses pendidikan.

Guru PAI di sekolah atau madrasah pada dasarnya melakukan kegiatan pendidikan Islam, yaitu "upaya normatif untuk membantu seseorang atau sekelompok orang peserta didik dalam mengembangkan pandangan hidup Islami”" (bagaimana akan 
menjalani dan memanfaatkan hidup dan kehidupan sesuai dengan ajaran dan nilai-nilai Islam), sikap hidup Islami, yang dimanifestasikan dalam keterampilan hidup seharihari.

Perwujudan sikap siswa ditunjukkan dengan kecenderungan terhadap suatu objek, peristiwa, dan sebagainya. Setiap siswa mempunyai sikap yang berbeda-beda terhadap suatu perangsang yang sama. Namun pendidikan kita saat ini sering dikritik masyarakat yang disebabkan oleh adanya sejumlah pelajar dan lulusan pendidikan yang menunjukkan sikap kurang terpuji, banyak pelajar yang terlibat tawuran, melakukan tindakan kriminal, penodongan, penyimpangan seksual dan sebagainya. Perbuatanperbuatan seperti ini sangat meresahkan masyarakat. Hal-hal tersebut masih ditambah lagi dengan meningkatnya jumlah pengangguran yang pada umumnya adalah tamatan pendidikan. Keadaan inilah yang semakin membuat potret hitam dunia pendidikan.

Berdasarkan permasalahan yang banyak timbul di dunia pendidikan inilah, guna mempersiapkan/melahirkan generasi-generasi pendidikan yang berkualitas, tidak hanya berintelektual tinggi, berwawasan luas tapi juga harus memiliki kemantapan emosi, etika moral dan spiritual yang luhur. Sehingga dapat dipahami betapa pentingnya peningkatan kecerdasan dan spiritual pada siswa dalam dunia pendidikan.

Banyak contoh di sekitar kita membuktikan orang yang memiliki kecerdasan otak saja belum tentu sukses berkiprah didunia pekerjaan, seringkali justru orang yang berpendidikan formal rendah banyak yang ternyata mampu lebih berhasil, karena mereka memiliki kecerdasan emosi seperti, ketangguhan mental, inisiatif, optimis dan kemampuan beradaptasi. ${ }^{1}$

Sikap spiritual merupakan pencerminan dari karakter religius. Religius merupakan nilai karakter yang berhubungan antara manusia dengan Tuhannya. Religius adalah nilai karakter yang menunjukkan pikiran, perkataan, dan tindakan seseorang selalu dilakukan berdasarkan nilai-nilai ketuhanan dan atau ajaran agamanya. SMK Pancasila sebuah lembaga sekolah menengah kejuruan yang terletak di Jombang tepatnya di kecamatan Mojowarno memiliki suatu visi yaitu menciptakan alumnus yang bertakwa mandiri dan profesional kemudian didukung dengan misinya yaitu: meningkatkan kualitas dan kuantitas alumnus yang siap kerja, menyiapkan tenaga

${ }^{1}$ Agustian, Ary Ginanjar, Rahasia Sukses Membangun Kecerdasan Emosi dan Spiritual- ESQ (Jakarta: Penerbit Arga. 2001), 41 
terampil yang memiliki etos kerja dan berkepribadian, menyiapkan wirausahawan yang handal dan mampu bersaing. Kemudain salah satu yang menjadi kebiasaan para siwa ketika memulai proses pembelajaran Pendidikan Agama Islam (PAI) Guru selalu mengajak para siswa untuk memulai pelajaran dengan membaca surat-surat pendek yang ada di dalam al-Qur-an atau Juz Amma, ini merupakan salah satu usaha dari guru meningkatkan sikap spiritual siswa.

\section{PEMBAHASAN}

\section{A. Peran Guru Pendidikan Agama Islam}

Peran guru pendidikan agama Islam akan diuraikan beberapa pendapat, yaitu menurut Watten B. Yangdikutip oleh Piet A. pengertian peran guru pendidikan agama Islam adalah tokoh terhormat dalam seorang sumber karena ia memberi ilmu pengetahuan, sebagai pembantu, sebagai wasit, sebagai detektif, sebagai obyek identifikasi, sebagai penyangga rasa takut, sebagai orang yang menolong memahami diri, sebagai pemimpinkelompok, sebagai orang tua atau wali, sebagai orang yang membina dan memberi layanan, sebagai kawan sekerja dan sebagai pembawa rasa kasih sayang. ${ }^{2}$ Sebelum penjelasan mengenai peran guru agama Islam dalam meningkatkan sikap spiritual siswa perlu diketahui beberapa peran guru agama Islam disekolah yaitu:

1. Guru agama Islam Sebagai Demonstrator Atau Pengajar

Guru hendaknya selalu mengusai bahan materi pelajaran yang akan di ajarkan, serta senantiasa mengembangkannya, dalam arti luas meningkatkan kemampuannya dalam ilmu pengetahuan yang dimilikinya, karena dalam hal ini akan sangat menentukan hasil belajar yang dicapai siswa. ${ }^{3}$

2. Guru Agama Islam Sebagai Pengelola Kelas

Dalam peranannya sebagai pengelola kelas, guru hendaknya mampu mengelola kelas sebagai lingkungan belajar serta merupakan aspek dari lingkuang sekolah yang perlu diorganisasikan. Tujuan umum pengelolaan kelas ialah menyediakan dan menggunakan fasilitas kelas untuk bermacammacam kegiatan belajar mengajar agar mencapai hasil yang baik. Sedangkan

2 P. Suhertian, Profil Pendidikan Profesional. (Surabaya: Andi Offset. 2011). 55

${ }^{3}$ Moh. Uzer Usman, Menjadi Guru Profesional (Bandung: Remaja Rosda Karya, 2012), 9 
tujuan khususnya adalah mengembangkan kemampuan siswa dalam menggunakan alat-alat belajar, menyediakan kondisi-kondisi yang memungkinkansiswa bekerja dan belajar, serta membantu siswa untuk memperoleh hasil yang diharapkan. ${ }^{4}$

3. Guru Agama Islam Sebagai Mediator Dan Fasilitator

Sebagai mediator dan fasilitator guru hendaknya memiliki pengetahuan dan pemahaman yang cukup tentang media pendidikan karena media pendidikan merupakan alat komunikasi untuk lebih mengefektifkan proses belajar mengajar tetapi guru harus memiliki pengetahuan dan ketrampilan untuk memilih dan menggunakan serta mengusahakan media pendidikan itu dengan baik. Sedangkan sebagai fasilitator guru hendaknya mampu mengusahakan sumber belajar yang berguna sertadapat menunjang tercapainya tujuan dalam proses belajar mengajar baik yang bersumber dari narasumber, buku bacaan, majalah, atau surat kabar.

4. Guru Agama Islam Sebagai Evaluator

Dalam proses belajar mengajar guru hendaknya menjadi seorang evaluator yang baik. Kegiatan ini dilakuakan untuk mengetahui apakah tujuan yang telah dirumuskan itu tercapai atau belum, dan apakah materi yang disampaikan sudah tepat. Tujuan lain dari penilaian diataranya adalah untuk mengetahui kedudukan siswa di dalam kelas atau kelompoknya. Dengan penilaian guru dapat mengetahui prestasi yang telah di capai siswa dalam proses belajar mengajar.

5. Guru Agama Islam Sebagai Pendorong Kreativitas

Kreativitas merupakan hal yang sangat penting dalam pembelajaran, dan guru dituntut untuk mendemonstrasikan dan menunjukkan proses kreativitas tersebut. Kreativitas merupakan sesuatu yang bersifat universal dan merupakan ciri aspek dunia kehidupan di sekitar kita. Kreativitas di tandai oleh adanya kegiatan menciptakan sesuatu yang sebelumnya tidak ada dan tidak dilakukan oleh seseorang atau adanya kecenderungan untuk menciptakan sesuatu. Sebagai orang yang kreatif, guru menyadari bahwa

${ }^{4}$ Moh. Uzer Usman, Menjadi Guru Profesional (Bandung: Remaja Rosda Karya,2012), 10 
kreativitas merupakan yang universal dan oleh karenanya semua kegiatannya di bimbing dan dibangkitkan oleh kesadaran itu. Akibat dari fungsi ini, guru senantiasa berusaha untuk menemukan cara yang lebih baik dalam melayani peserta didik, sehingga peserta didik akan menilainya bahwa ia memang kreatif dan tidak melakukan sesuatu secara rutin saja. Kreativitas menujukkan bahwa apa yang akan dilakukan oleh guru sekarang lebih baik dari yang telah dikerjakan sebelumnya dan apa yang dikerjakan di masa mendatang lebih baik dari sekaranag. ${ }^{5}$

\section{B. Sikap Spiritualitas}

Pengertian Sikap Dalam Kamus Besar Bahasa Indonesia, sikap memiliki beberapa arti antara lain: tokoh atau bentuk tubuh, cara berdiri, perbuatan yang berdasarkan pada keyakinan dan pendirian, perilaku, gerak-gerik. Sikap merupakan kesiapan untuk timbulnya suatu perbuatan. Sikap juga merupakan organisasi keyakinan-keyakinan seseorang mengenai objek atau situasi yang relatif tetap, yang memberi dasar kepada orang untuk menanggapi dalam cara tertentu. ${ }^{6}$ Menurut Azwar struktur sikap terdiri dari tiga komponen yang saling mendukung yaitu komponen kognitif, komponen afektif, dan komponen konatif. Komponen kognitif merupakan perwujudan apa yang dipercayai oleh seseorang pemilik sikap, komponen afektif merupakan perasaan yang bersangkutan dengan aspek emosional, dan komponen konatif merupakan aspek yang mampu mendorong seseorang melakukan sesuatu atau berperilaku. Pada dasarnya, sikap merupakan kecenderungan siswa untuk berperilaku dengan cara tertentu. Perwujudan sikap siswa ditunjukkan dengan kecenderunganterhadap suatu objek, peristiwa, dan sebagainya. Setiap siswa mempunyai sikap yang berbeda-beda terhadap suatu perangsang yang sama.

Sikap spiritual merupakan pencerminan dari karakter religius. Religius merupakan nilai karakter yang berhubungan antara manusia dengan Tuhannya. Religius adalah nilai karakter yang menunjukkan pikiran, perkataan, dan tindakan

${ }^{5}$ E. Mulyasa. Menjadi Guru Profesional. (Bandung: Remaja Rosda Karya, 2005), 51

${ }^{6}$ Yudrik Jahja, Psikologi Perkembangan. (Jakarta: Kencana, 2011), 67 
seseorang selalu dilakukan berdasarkan nilai-nilai ketuhanan dan atau ajaran agamanya.

Religius adalah sikap dan perilaku patuh dalam melaksanakan ajaran agama yang dianutnya, memiliki sikap toleransi terhadap pelaksanaan ibadah agama lain, serta hidup rukun dengan pemeluk agama lain. (Syamsul Kurniawan, 2014 : 41). Menurut penulis sikap spiritual adalah gabungan antara sikap dan spiritual berdasarkan rukun iman, rukun islam dan ihsan sehingga menciptakan manusia yang utuh.

\section{Surat Pendek (Juz 'Amma)}

Juz adalah sebuah cara pembagian terhadap bagian-bagian dari Alqur'an, dimana keseluruhan Alqur'an dipecah menjadi 30 juz. Tujuan pembagian ini adalah untuk memudahkan mereka yang ingin menyelesaikan pembacaan (membaca) Alqur'an dalam 30 hari (1 bulan). Kata Juz itu sendiri dalam bahasa Arab mengandung arti 'bagian'. Maka, satujuz. Alqur'an sama dengan satu bagian

al-Qurean. Juz 30, atau lebih dikenal sebagai Juz. Amma (جز ) merupakan bagian juz yang terakhir dalam Al-qurean. Juz ini ditandai dengan kata pertama 'amma pada surah An-naba ${ }^{e e}$ ayat satu dan berakhir dalam surat $A n-N a s$.

Sebagian besar dalam juz ini adalah surah - surah pendek, Jus 'Amma tewrdiri dari 37 buah surah pendek dan 34 diantaranya merupakan surat makkiah, artinya surat yang diturubkab di makkah sementara sisanya 3 surat adalah surat madaniah, yaitu surat Al-Bayyinah, Ar-zalilah dan surat An-Nasr. Pembacaan dan penghafalan Al-qur ${ }^{\text {ee }}$ n pada bagian ini banyak dilakukan oleh kaum muslimin dikarenakan surat yang terdapat dalam juz ini tergolong suratsurat pendek.

Dalam tradisi rakyat Indonesia, Juz 30 atau Juг „Amma lebih banyak diketahui dari kitab atau buku yang disusun secara terpisah dari juz lainnya dalam buku khusus yang hanya menuliskan surah-surah dalam Juz 30. Saat ini bukubuku yang berisikan juz 30 Alqur'an dalam dunia pendidikan digunakan pada tingkatan kedua setelah fase pengenalan huruf Hijaiyah, kemudian melanjutkan pada fase terakhir yaitu menggunakan dengan jumlah Juz yang lengkap. 
Berdasarkan pengertian juz, amma di atas maka pada penelitian ini istilah tadaruz Juz ,,amma diganti menjadi membaca Alqur'an, karena pada hakikatnya tadrusjuz „amma adalah membaca Alqur'an dikhususkan pada juz akhir Alqur'an.

\section{ANALISIS}

A. Peran Guru PAI Dalam Meningkatkan Sikap Spiritual Siswa Melalui Pembacaan Surat-surat Pendek

1. Peran Guru Melalui Konsistensi (istiqomah)

Pengembangan konsistensi ini meliputi: Pemberian kewajiban kepada siswa untuk melakukan shalat dzuhur berjama'ah, mebiasakan siswa untuk membaca ayat-ayat Alqur'an dan Asmaul Husna ketika akan memulai pelajaran setiap hari. menumbuh kembangkan kepercayaan diri yang kuat dan kesadaran diri yang kuat dengan penanaman nilai pada siswa bahwa Allah akan mengangkat derajat manusia dengan ilmu yang dimilikinya. Mendorong dan mengarahkan mereka untuk mampu mengontrol dan mengendalikan emosinya. Memberikan teladan yang baik serta mengarahkan mereka untuk berbuat baik. Sebagaimana hasil wawancara peneliti bahwa dalam hal ini peran yang telah dilakukan guru di SMK Pancasila dengan mewajibkan siswa untuk menjalankan shalat dhuhur berjamaa,ah dan membiasakan siswa untuk membaca ayat-ayat suci Alqur'an serta Asmaul Husna setiap hari. Sebagaimana telah dijelaskan bahwa istiqamah adalah aktivitas yang dilakukan secara terus menerus sehingga tercapai hasil yang diinginkan, maka dalam pendidikan pembiasaan adalah sebagai metode.

Hal ini sesuai dengan pendapat Arif dalam bukunya yaitu metode pembiasaan diyakini sebagai metode paling efektif dalam mencapai tujuan pembelajaran, karena dengan pembiasaan siswa dibiarkan untuk berfikir, bersikap dan bertindak sesuai dengan tuntutan Islam. Penerapan metode pembiasaan sangat efektif diterapkan dalam mencapai tujuan pembelajaran hal ini karena anak pada usia-usia ini memiliki "rekaman" ingatan yang kuat dan kondisi kepribadian yang belum matang, sehingga mereka mudah 
terlarut dengan kebiasaan-kebiasaan yang mereka lakukan sehari-hari. ${ }^{7}$

a. Peran Guru Melalui Kerendahan Hati (tawadu')

Adapun dalam menegembangkan kerendahan hati peran guru meliputi: melibatkan siswa secara optimal dalam pembelajaran baik secara fisik, sosial, maupun emosional, melatih siswa untuk bertanggung jawab, membiasakan siswa untuk peka terhadap kata hati diri sendiri yang berpijak pada kebenaran, melatih siswa mampu menunda kenikmatan, serta melatih siswa untuk mampu bangkit dari tekanan emosi. Sebagaimana hasil wawancara peneliti bahwa dalam hal ini peran yang telah dilakukan guru di SMK Pancasila dengan Mendorong siswa untuk aktif dalam organisasi baik yang ada di dalam seperti osis dan pramuka, serta mendorong mereka untuk aktif dalam kegiatan-kegiatan atau event-event yang diadakan sekolah maupun di luar sekolah.

Dalam hal ini peran guru di SMK Pancasila dengan melibatkan siswa secara optimal dalam kegiatan belajar mengajar serta dalam berorganisasi sehingga siswa dapat bersosialisasi dengan baik tanpa memandang harta, pangkat maupun jabatan. Kerendahan hati bukan berarti merendahkan diri dihadapan manusia akan tetapi adalah tidak memandang diri lebih tinggi daripada orang lain. Orang yang rendah diri menyadari bahwa apa yang dia miliki baik berupa bentuk fisik yang cantik maupun tampan, ilmu pengetahuan, harta kekayaan, kedudukan dan pangkat, hanyalah karunia Allah SWT.

b. Peran Guru Melalui Berusaha Dan Berserah Diri (tawakkal)

Peran guru dalam mengembangkan kesungguhan siswa antara lain: melibatkan siswa secara langsung baik secara fisik, materi maupun emosional dalam pembelajaran dan kegiatan-kegiatan siswa. Mengajak siswa untuk terlibat langsung dalam kegiatan-kegiatan yang dilakukan agar siswa dapat mengembangkan inisiatifnya dan kreatifitasnya, menuntut aktif siswa dalam proses belajar mengajar, memberikan kebebasan siswa untuk mengeluarkan pendapat dan mengekspresikan apa yang mereka inginkan.membantu siswa yang bermasalah dengan duduk bersama untuk menyelesaikan masalahnya.

Sebagaimana hasil wawancara peneliti bahwa gengan demikian peran guru dalam mengembangkan sikap berusaha dan berserah diri di SMK

${ }^{7}$ Arif, A. Pengantar Ilmu dan Metodologi Pendidikan Islam. (Jakarta: Ciputat Press, 2002), 110 
Pancasila, membantu siswa untuk menyelesaikan masalahnya dan menyerahkannya kepada Allah SWT,

Hal ini Sesuai dengan teori diantara hikmah tawakkal yaitu ketika seseorang sudah merencanakan sesuatu dengan cermat, mengerahkan segala tenaga, dan melaksanakan rencananya dengan penuh kedisiplinan, dan menyerahkan hasilnya kepada Allah, namun keinginanya tidak tercapai, maka itu tidak membuat dirinya putus asa. Pada setiap proses yang akan dan telah kita lalui, tertadap takdir atau hukum ketetapan tuhan yang bersifat pasti. ${ }^{8}$

c. Peran Guru Melalui Ketulusan (keikhlasan)

Seperti yang sudah dikemukakan di atas bahwa untuk mengembangkan kemampuan berempati siswa peran guru meliputi: pengembangan sikap ketulusan siswa dengan cara di adakannya yazis, infak dan sahodaqah, penyembelihan hewan kurban, mengadakan kemah bakti sosial, serta merasakan apa yang dirasakan peserta didik, melatih siswa mampu mengenali emosi orang lain sehingga menumbuhkan sikap empati pada siswa, menumbuhkan sikap saling percaya dan menyelaraskan diri dengan berbagi macam orang, menanamkan sikap peduli terhadap sesama, menanamkan pada siswa untuk ikhlas beramal serta mengerjakan apa yang diwajibkan dan yang di sunnahkan.

Selaras dengan pendapat Ginanjar yakni niat yang ikhlas berarti niat yang didasarkan semata-mata hanya untuk mencari ridha Allah SWT. Prinsip mencari ridha Allah itu membuat hati seseorang menjadi tentram dan bahagia juga menjaga kesetabilan emosi. ${ }^{9}$ Sedangkan peran guru untuk mengembangkan sikap ketulusan (keikhlasan) di SMK Pancasila dengan melalui tindakan-tindakan langsung seperti pembagian zakat, infak dan shodaqah, bantuan moril kepada yang membutuhkan, menanamkan sikap tolong menolong dan peduli terhadap antar sesama. Sehingga antara teori dan praktiknya dapat berjalan dengan seimbang. Beramal dengan sebaik-baiknya sama dengan

8 Agustian, Ary Ginanjar, Rahasia Sukeses Membangun Kecerdasan Emosi dan Spiritual- ESQ, Jakarta: Penerbit Arga. 2001), 212.

9 Agustian, Ary Ginanjar, Rabasia Sukses Membangun Kecerdasan Emosi dan Spiritual- ESQ Jakarta: Penerbit Arga. 2001), 133 
melakukan pekerjaan secara profesional. Bekerja secara profesional berarti bekerja untuk menghasilkan sesuatu dengan usaha atau jerih payahnya sendiri untuk kebajikan diri sendiri juga untuk orang lain.

d. Peran Guru Melalui Totalitas (kaffah)

Dalam mangembangkan totalitas siswa peran guru adalah dengan cara mengadakan kegiatan-kegiatan sosial baik yang di adakan sekolah maupun kegiatan yang dilakukan tingkat desa atau kecamatan, memberikan kesempatan pada siswa untuk mengelola kantin, membimbing dan mendorong siswa untuk aktif dalam kegiatan-kegiatan dan organisasi yang dilakukan disekolah maupun diluar sekolah.siswa juga dituntut untuk aktif dalam kegiatan belajar mengajar. selain itu siswa juga dituntut untuk aktif dalam kegiatan-kegiatan keagamaan

Sesuai dengan teori totalitas artinya keseluruhan, dalam Alqur'an disebutkan bahwa seseorang harus masuk Islam secara keseluruhan. Seseorang yang masuk islam secara kaffah maka akan menjalankan ajaran agamanya secara keseluruhan baik secara fisik maupun secara batin. Dia akan komitmen melaksanakan ajaran islam seperti perintah mentaati rukun iman, langsung dari Allah dan bersyahadat kepada Allah. ${ }^{10}$

Selain itu untuk mengembangkan sikap totalitas pada siswa difokuskan bagi guru untuk menjadi tauladan dalam menegakkan aturan atau disiplin dalam pembelajaran, maupun dalam menjalin hubungan baik dengan masyarakat. Dalam hal ini peran guru agama yang telah dilakukan di SMK Pancasila adalah mendorong siswa untuk aktif dalam organisasi yang ada di dalam sekolah maupun di luar sekolah.

e. Peran Guru Melalui Sikap Integritas Dan Penyempurnaan (ihsan)

Integritas adalah perilaku jujur dan dapat dipercaya. Integritas merupakan kesamaan antara perkataan, pikiran dan perbuatan. ${ }^{11}$ Sesuai dengan yang dikatakan oleh guru PAI yaitu sebagai seorang guru tentu saja kita memberikan teladan yang baik, karena guru itu digugu dan ditiru jadi

\footnotetext{
10 Agustian, Ary Ginanjar, Rahasia Sukses Membangun Kecerdasan Emosi dan Spiritual- ESQ, Jakarta: Penerbit Arga. 2001), 265

11 Agustian, Ary Ginanjar, Rahasia Sukeses Membangun Kecerdasan Emosi dan Spiritual- ESQ, Jakarta: Penerbit Arga. 2001), 129
} 
apa yang kita lakukan tentu saja menjadi contoh bagi siswa baik perkataan maupun perbuatan. Adapun peran guru dalam integritas dan penyempurnaan meliputi: guru memberikan contoh keteladanan dengan ikut aktif dalam kegiatan shalat dhuhur berjama'ah serta memberikan contoh yang baik melalui sikap dan perilaku. Sehingga antara teori dan praktiknya dapat berjalan dengan seimbang.

Hal ini selaras dengan pendapat yaitu orang yang memiliki integritas dalam melakukan pekerjaan tidak membutuhkan tidak membutuhkan pujian atau tepuk tangan dari orang lain. Dia melakukanya dengan penuh kesungguhan, ketuntasan dan bekerja dengan hati. Ihsan menghendaki manusia untuk menyadari kehadiran Allah dan berperilaku sebaik-baiknya ,Ihsan membuat seseorang untuk berperilaku maksimal, karena dia merasa diawasi Allah.

\section{B. Faktor Pendukung dan Penghambat Peran Guru Dalam Meningkan Sikap Spiritual Siswa di SMK Pancasila Mojowarno Jombang}

1. Faktor pendukung

Adapun faktor yang mendukung dalam meningkatkan sikap spiritual siswa adalah sarana dan prasarana di SMK Pancasila yang dirasa sudah cukup memadai bagi pelaksanaan untuk meningkatkan spiritual siswa dengan adanya sarana ibadah yang dimiliki sendiri seperti masjid.

2. Faktor Penghambat

Peran guru dalam meningkatkan sikap spiritual siswa di SMK pancasila Mojowarno ternyata berjalan kurang maksimal karena beberapa faktor-faktor yang menghambat sebagi berikut:

a Terbatasnya waktu pertemuan dan interaksi antara siswa dan guru, hubungan para guru di semaksimal mungkin dalam memantau tingkah laku, kepribadian, maupun perkembangan siswa itu sendiri, termasuk di dalamya sikap spiritual siswa.

b. Sikap spiritual siswa merupakan sikap tidak permanen sehingga dalam peningkatannya terkadang mengalami kenaikan tetapi tidak jarang juga mengalami penurunan.

c. Kurangnya motivasi atau perhatian orang tua ketika siswa berada dalam 
lingkungan keluarga maupun lingkungan masyarakat.

d. Tidak adanya penilaian tertulis secara langsung mengenai sejauh mana sikap spiritual siswa, sehingga para guru hanya bisa memantau dan menilai siswa melalui sikap mereka sehari hari dan mengadakan kerja sama dan interaksi terhadap wali murid mengenai perkembangan sikap spiritual siswa itu sendiri.

3. Solusi

Dari beberapa faktor-faktor pendukung dan penghambat yang telah penulis temukan adakalanya seorang guru dapat memberikan waktu pertemuan atau jam tambahan untuk memaksimalkan dalam memberikan motivasi kepada siswa untuk memaksimalkan penanaman sikap spiritual terhadap siswa, karena mengingat bahwa sikap spiritual merupakan sikap yang tidak permanen sehinga dalam penanamanya terkadang mengalami penurunan, selebihnya perhatian orang tua juga sangat berpengaruh dalam proses peningkatan spiritual siswa itu sendiri.

\section{KESIMPULAN}

Peran guru dalam meningkatkan sikap spiritual siswa melalui surat-surat pendek di SMK Pancasila Mojowarno meliputi konsistensi (istiqomah), kerendahan hati (tawadu), berusaha dan berserah diri (tawakal), ketulusan(keikhlasan), totalitas (kaffah), intergitas dan penyempurnaan (ihsan). Sikap spiritual siswa SMK Pancasila Mojowarno secara akademik, keahlian, kematangan emosional dan moral, ialah hasil dari peran guru dalam meningkatkan sikap spiritual melalui pemahaman internal dan praktik lapangan. Faktor-faktor yang menjadi pendukung dalam mengembangkang SQ adalah sarana dan prasarana yang memadai, serta lingkungan yang nyaman dan kondusif karena berada dalam lingkungan pedesaan. Adapun factor - Faktor yang menghambat pengembangan SQ adalah: terbatasnya waktu pertemuan dan interaksi antara guru dan siswa. Kurangnya motivasi dan perhatian orang tua. Tidak adanya penilain secara tertulis dalam kecerdasan emosional dan spiritual.

\section{DAFTAR PUSTAKA}

Suhertian, P. Profil Pendidikan Profesional. Surabaya: Andi Offset. 2011.

Uzer Usman, Moh. Menjadi Guru Profesional, Bandung: Remaja Rosda Karya, 2012. 
Mulyasa. E. Menjadi Guru Profesional. Bandung: Remaja Rosda Karya, 2005.

Jahja, Yudrik, Psikologi Perkembangan. Jakarta: Kencana, 2011.

Arif, A. Pengantar Ilmu dan Metodologi Pendidikan Islam. Jakarta: Ciputat Press, 2002.

Agustian, Ary Ginanjar, Rahasia Sukses Membangun Kecerdasan Emosi dan Spiritual- ESQ Jakarta: Penerbit Arga. 2001. 